\title{
MARKET TIMING AND THE USE OF DEBT FOR STOCK REPURCHASES
}

S. Drew Peabody, University of Texas at Dallas, Richardson, Texas, U.S.A. Jeffrey A. Manzi, University of Texas at Dallas, Richardson, Texas, U.S.A.

dx.doi.org/10.18374/RBR-20-2.3

\begin{abstract}
Recent increases in stock repurchases among U.S. corporations coupled with a historically low cost of debt since the Global Financial Crisis has created media speculation that firms in recent years are paying for their expanding share buyback programs with debt. This study examines this phenomenon and the likelihood of debt-financed repurchases during different interest rate environments and finds that debt-financed repurchases have increased substantially in recent years, especially in the presence of relatively low interest rates. Firms that make these repurchases tend to be bigger, more levered and make larger repurchases - a phenomenon that is especially pronounced in the years following the Global Financial Crisis. This study suggests that managers may time debt markets in order to repurchase stock when the prevailing cost of debt is relatively low.
\end{abstract}

Keywords: Debt Market Timing; Debt-financed Repurchases; Low Interest Rates; Buybacks 